\title{
The influence of the principal's leadership and the role of the committee on the teacher discipline
}

\author{
Marini Sartika ${ }^{1}$, Happy Fitria ${ }^{2}$, Achmad Wahidy ${ }^{3}$ \\ ${ }^{1}$ SMA Negeri 1 Gelumbang \\ ${ }^{2}$ Universitas PGRI Palembang
}

\section{Article Info \\ Article history: \\ Received Jul $12^{\text {th }}, 2021$ \\ Revised Aug $7^{\text {th }}, 2021$ \\ Accepted Aug $30^{\mathrm{h}}, 2021$ \\ Keyword: \\ Principal Leadership \\ Committee Role \\ Teacher Discipline}

\begin{abstract}
This study aims to determine the effect of the principal's leadership and the role of the committee on teacher discipline at SMA Negeri Muara Enim . This research uses quantitative methods with correlational research type. The population was 179 teachers who were in sub-district 7 Muara Enim Regency with a sample of 124 teachers. The sampling technique is a sampling area. Data collection techniques use questionnaires and documentation. Data were analyzed using correlation analysis techniques and multiple regression. The results showed that: (1) The leadership of the principal has a significant and significant effect on the discipline of SMA teachers in Muara Enim Regency (2) The role of the committee has a significant and significant effect on the discipline of teachers of SMA Negeri in Muara Enim Regency; and (3) The leadership of the principal and the role of the school committee together have an effect and are significant on the performance of SMA teachers in Muara Enim Regency.
\end{abstract}

(C) 2021 The Authors. Published by IICET.

This is an open access article under the CC BY-NC-SA license (https://creativecommons.org/licenses/by-nc-sa/4.0

\section{Corresponding Author:}

Marini Sartika

SMA Negeri 1 Gelumbang

Email: marinisartika78@gmail.com

\section{Introduction}

Education is a system . As a system, educational activities are built into several components, namely educators, students, educational goals, educational tools, and the educational environment . Each component has their respective functions in order to achieve educational goals. The success of the process of education greatly determined by the ability of leaders of education was alone in the unit school that lead is the head of school, it is in line with the opinion [1].The principal is one of the determinants of the success of every education effort and the most influential component in creating quality education processes and autcomes [2].

In an organization 's success or failure in carrying out tasks and organize diperngauhi by leadership and supported by the capacity of the organization that is adequate, then the organize system of government that is both (Good Governance) materialized otherwise weaknesses leader in Indonesia is one of the causes of collapse of bureaucratic work [3]

The role and the society set includes space scope of the vast includes roles as well as individual, group , family , organization of professions , employers and organizations of society , in Act 20 of 2003. The ordinary so-called committee of school 
"The school committee's direct involvement in the administrations of the education, seen where the school committee paid attention and built commitment with the community to support school program saved at improving school quality" in [4]

The school of comitee must positions themselves as partners with the principal who can be consulelted about the future of the school [5].

The statement that was supported by the results of the study of [6] Imansyah (2020) which is entitled " The Effect of Leadership Head of School and Participation Committee of the School Of Performance Guru" show leadership head of school effect of $10.3 \%$, the participation of a committee of school effect of $6.0 \%$ in together influence positively and significantly to the performance of teachers.

Teachers as energy educator is one of the components in the process of education is required in order to have a discipline that is good. Discipline teachers often become the foundation in achieve the quality expectations of graduates of educational institutions. By because it is, the presence of teachers in the process of learning to teach is still holding the role is important. In the level of micro- technical, teachers as workers educator is a leader of education, he is very decisive in the process of learning in the classroom, and the role of leadership that will be reflected on how teachers carry out the role and duties .

Teachers discipline in the process of learning to teach a factor Yag greatly determine the formation of the quality of schools that will have implications on the quality of the output of education for the participant students after completing his education at the school the school. Discipline for teachers is part not in carrying out duties and obligations [7].

Observations in several schools that became the object of research, discipline the teacher in fully performed by both, is often too late and did not arrive at school.The average they already use absentee with a finger print. The applicability of attendance receipts finger print also often misused for example a teacher come just roll and only then out again from school without teaching, when the hours of home teachers come back to the roll . $\mathrm{H}$ al this will affect and greatly interfere with the process of learning and teaching students .

The existence of the influence of the head of school and the role of committees school things this can dihaeapkan can help the problem of discipline teachers and all problems. So it can produce a school that qualified and participants of students who qualified .

Can be formulated hypothesis of the research it is 1 . There is the influence of the significant leadership of the Head of the school to discipline a high school teacher of State in the District of Muara Enim . 2. There is the effect of the significant role of the Committee of the school to discipline a high school teacher of State in the District of Muara Enim . 3. There is the effect of the significant leadership of the Head of the school and the role of the Committee of the School are jointly to discipline teachers state school in Muara Enim.

\section{Method}

[8] the research method is a scientific way to obtain data with specific purposes and uses. Research that uses a questionnaire as a method for collecting data that adapts to the objectives to be achieved in investigating the influence of school leadership and the role of the committee on teacher discipline, this research is included in led research. The population in this study were teachers at state schools in sub-district 7, Muara Enim district, sampling using cluster sampling techniques. Using the Yamane formula by determining the error limit of 5\% had an accuracy rate of $95 \%$. So a sample of 124 people (made), this number is the sample of the study.

\section{Results}

Hypothesis testing is done by using no technique and determination, coefficient test $(\mathrm{t})$ and multiple coefficient regression ( $\mathrm{F}$ test).

\section{Hypothesis testing 1}

\section{Correlation Analysis Test}

The calculation of statistical analysis was built to see whether there was a significant influence between the principal's leadership variable (X1) on teacher discipline (Y). 
Table 1. Results of Correlation Statistical Analysis and Coefficient of Determination

\begin{tabular}{lllll} 
Model & R & R Square & Adjusted R Square & Std. Error of the Estimate \\
\hline 1 & $.350^{\mathrm{a}}$ & .122 & .115 & 8.027 \\
\hline
\end{tabular}

$\mathrm{R}=0.350$, which means that the principal leadership variable $(\mathrm{X} 1)$ on teacher discipline $(\mathrm{Y})$ has a low relationship. $\mathrm{R} 2=0.122$ which means that $12.2 \%$ of the principal's leadership variable (X1) affects teacher discipline $(100-12.2 \%=87.8 \%)$ which is influenced by other variables not included in this study.

From the results of the table above, the $\mathrm{R}$ number is 0.350 because the correlation value is between 0.20 0.399 [8] it can be concluded that there is a low influence between the leadership of the principal on teacher discipline.

\section{Coefficient of Determination}

The coefficient of determination to find out how much influence the independent variable has. the dependent variable. From the output results in Table 1, it is known that R2 is $12.2 \%$, while $87.8 \%$ is influenced by other factors.

\section{Regression Coefficient Test (Partial Test)}

The regression coefficient test or $t$ test aims to test whether the relationship is significant or not, so the $t$ test is used.

Table 2. Principal Leadership t test

\begin{tabular}{|c|c|c|c|c|c|c|}
\hline \multirow[b]{2}{*}{ Model } & & \multicolumn{2}{|c|}{ Unstandardized Coefficients } & \multirow{2}{*}{$\begin{array}{l}\text { Standardized } \\
\text { Coefficients } \\
\text { Beta }\end{array}$} & \multirow[b]{2}{*}{$\mathrm{t}$} & \multirow[b]{2}{*}{ Sig. } \\
\hline & & $\mathrm{B}$ & Std. Error & & & \\
\hline 1 & (Constant) & $\begin{array}{l}45.432 \\
.395\end{array}$ & $\begin{array}{l}6.951 \\
.096\end{array}$ & .350 & $\begin{array}{l}6.536 \\
4.126\end{array}$ & $\begin{array}{l}.000 \\
.000\end{array}$ \\
\hline
\end{tabular}

The results obtained for $\mathrm{t}$ Table 1.97 If calculated $\mathrm{t}$ Table $(4.126>1.97)$ or a significance value of 0.000 $<0.005$ then H0 is rejected and Hal is accepted. So it can be concluded that the principal's leadership has a significant effect on teacher discipline.

\section{Hypothesis Testing 2}

\section{Correlation Analysis Test}

The calculation of correlational statistical analysis is to determine whether there is a significant influence between the committee role variable (X2) on teacher discipline (Y).

Table 3. Results of statistical analysis of correlation and coefficient of determination

\begin{tabular}{lllll}
\hline Model & $\mathrm{R}$ & R Square & Adjusted R Square & Std. Error of the Estimate \\
\hline 1 & $.245^{\mathrm{a}}$ & .060 & .052 & 8.309 \\
\hline
\end{tabular}

$\mathrm{R}=0.245$, which means that the role variable of the school committee (X2) on teacher discipline has a low relationship

\section{Coefficient of Determination}

The coefficient of determination is used to determine how much influence the independent variable has on the dependent variable. From the table above, it is known that the $\mathrm{R}$ Square value is $6.0 \%$, while $94 \%$ is influenced by other factors not included in this study

\section{Regression Coefficient Test (Partial Test)}

The regression coefficient test ( $t$ test) aims to test whether each independent variable, namely the role of the committee (X2), has a significant effect on teacher discipline (Y). 
Table 4. The results of the $t$ test for the variable $\mathrm{X} 2-\mathrm{Y}$

\begin{tabular}{|c|c|c|c|c|c|c|}
\hline \multirow[b]{2}{*}{ Model } & & \multicolumn{2}{|c|}{$\begin{array}{l}\text { Unstandardized } \\
\text { Coefficients }\end{array}$} & $\begin{array}{l}\text { Standardized } \\
\text { Coefficients }\end{array}$ & & \multirow[b]{2}{*}{ Sig. } \\
\hline & & B & $\begin{array}{l}\text { Std. } \\
\text { Error }\end{array}$ & Beta & & \\
\hline 1 & (Constant) & 54.093 & 7.171 & & 7.544 & .000 \\
\hline & Peran Komite & .271 & .097 & .245 & 2.786 & .006 \\
\hline
\end{tabular}

The result obtained for $t$ table is 1.976. If $t$ count $>t$ table (2.786-1.976) or the significance value $=0.000$ $<0.005$, then $\mathrm{H} 02$ is rejected and Ha2 is accepted. So it can be concluded that the role of the committee has a significant effect on teacher discipline.

\section{Hypothesis Testing 3}

\section{Correlation Analysis Test}

The calculation of multiple correlation statistical analysis is to determine the relationship between the independent variable and the dependent variable.The calculation of multiple correlation statistical analysis is to determine the relationship between the independent variable and the dependent variable

Table 5. Statistical Analysis Results of Multiple Correlation and Determination Coefficient

Model Summary ${ }^{\mathrm{b}}$

\begin{tabular}{lllll}
\hline Model & $\mathrm{R}$ & $\mathrm{R}$ Square & Adjusted R Square & Std. Error of the Estimate \\
\hline 1 & $.350^{\mathrm{a}}$ & .123 & .108 & 8.060 \\
\hline
\end{tabular}

a. Predictors: (Constant), Peran Komite, Kepemimpinan Kepala Sekolah

b. Dependent Variable: Disiplin Guru

Which means that the variable principal leadership (X1) and committee participation (X2) on teacher discipline $(\mathrm{Y})$ has a low relationship.

\section{Coefficient of Determination}

The coefficient of determination is used to determine how much influence the independent variable has on the dependent variable. From the results of the summary model output in Table 5, it is known that the $\mathrm{R}$ Square value is $12.3 \%$. while $87.7 \%$ influenced by other factors not included in this research.

\section{Coefficient Test (Simultaneous Test)}

Multiple correlation coefficient test or simultaneous test ( $F$ test) aims to determine the effect of independent variables on the dependent variable.

Table 6. F Test Statistics

\begin{tabular}{lllllll}
\hline \multicolumn{2}{l}{ Model } & Sum of Squares & df & Mean Square & F & Sig. \\
\hline 1 & Regression & 1098.994 & 2 & 549.497 & 8.459 & $.000^{b}$ \\
& Residual & 7859.805 & 121 & 64.957 & & \\
& Total & 8958.798 & 123 & & &
\end{tabular}

a. Dependent Variable: Disiplin Guru

b. Predictors: (Constant), Kepemimpinan Kepala Sekolah, Peran Komite

Based on Table 6. It is known that the calculated $F$ value of 8.459 with a significance value of 0.000 compared to the F table distribution value of 3.07. Hypothesis test: $\mathrm{F}$ count $<\mathrm{F}$ table $=\mathrm{H} 03$ accepted and Ha 3 rejected $\mathrm{F}$ count $>\mathrm{F}$ accepted $=\mathrm{H} 03$ rejected and $\mathrm{Ha} 3$ is accepted. So 8,459>3.07 with a significance value $=$ $0,000<0.005$ then $\mathrm{H} 03$ is rejected and Ha3 is accepted so that it can be concluded that the leadership of the principal and the role of the school committee jointly or simultaneously influence teacher discipline. 


\section{Discussion}

\section{The influence of the principal's leadership on teacher discipline}

Based on the research results, it shows that the principal's leadership has a significant effect on teacher performance. The results of the calculation of the hypothesis show that the principal's leadership has an influence on teacher discipline by $12.22 \%$, while the rest is influenced by other variables. The t test results also show that the principal's leadership affects the discipline of teachers at Muara Enim State Senior High School. This research is in line with [9] which states that there is a fairly good influence between the leadership of the principal on teacher discipline because there are efforts from the head as if to enforce discipline cooperatively.

\section{The Influence of the Role of the Committee on Teacher Discipline}

Based on the research results, it shows the role of the school committee on teacher discipline. The school committee is an independent body that accommodates community participation in the context of improving the quality, equity and efficiency of education management in schools. The results of the calculation of the hypothesis show that the role of the school committee has an influence on teacher discipline $6 \%$ while $94 \%$ is influenced by other variables. The results of the $t$ test also show that the role of the committee has an effect on teacher discipline at Muara Enim Senior High School.

In line with research, [10] states that the role of the committee is very influential on the performance of elementary school teachers in Bandar Lampung with a result of $93 \%$, which means that the committee can play an important role in school progress.

\section{The Influence of Principal Leadership and the role of the Committee on Teacher Discipline}

The significant relationship between the leadership of the principal and the school committee is a finding that shows the importance of the effectiveness of both of them which can collaborate together in improving the quality of the school. Principals who are responsible as educators, managers, administrators, supervisors, leaders, innovators and motivators. School committees serve as input in determining school policies by providing direction on the quality of school services by making program planning, implementing educational programs, and then carrying out management of educational resources and monitoring educational output.

This research is in accordance with [10] which states that the influence of leadership is $10.3 \%$, committee participation is $6 \%$, which shows that the better the leadership influence, the better the performance, the better the committee participation, the better the performance.

\section{Conclusions}

It can be concluded from the research results that principal leadership has a significant effect on teacher discipline, the role of the committee has an ef was funded independent.fect on teacher discipline; and the leadership of the principal and the role of the committee together have a significant effect on teacher discipline at Muara Enim State High School.

\section{References}

Mulyasa,E.(2011) .Manajemen Kepala Sekolah Profesional.Bandung;PT.Remaja Rosdakarya.

Kartini,D.,Kristiawan,M.,\&Fitria,H (2020) The Influence of Principals Leadership,Academic Supervision, and Professional Competence towards Teachers Performance. International Journal and of Progressive Sciences andTechnologies (IJPSAT) pp.156-164.

Fitria,H.,Muchtar,M.,\&Akbar,M .(2017) The Effect of Organizational Structure And Leadership Style on Teacher Performance In Private Secondary School.IJHCM (International Jornal of Human Capital Management),1(02), 101-112.

Utama, H., Kristiawan, M., \& Lian B. (2020) The Impact of Full Day School Implementation on Teacher Work Discipline Journal of Management, Leadership, and Education Supervision Volume.5 No.1 January-June 2020.

Effendi,R.,Wardiah,D.,\& Lian B (2020).SchoolCommitee Strategy in Improving the Qality of Educational Services.International Journal of Progressive Sciencies and Technologies (IJPSAT).Vol 20.1April 2020, pp 212-220 
Imansyah., Arafat, Y., \& Wardiah, D (2020) The Influence of School Committee Leadership and Participation on Teacher Performance. Journal of Education Management and Supervision, PGRI University of Palembang

Wahyudi, Adi. 2012. The effect of work discipline, work motivation and supervision of the principal on teacher performance. Volume 1 no.2 2012 http://ejournal..unnes.ac.id/sju/index.php/eeaj.

Sugiyono (2019) Metode Penelitian Pendekatan Kuantitatif,,dan Kualitatif,dan R\&D. Bandung:Alfabeta.

Arjunaita., Fitria., H., \& Rohana. (2020) The role of the principal in implementing teacher discipline Tambusai Journal of Education Volume 4 no. 2 of 2020

Sari (2017) The influence of the leadership role of school principals and the role of school committees on the performance of elementary school teachers in Bandar Lampung, FKIP UNILA Journal. 